\title{
Rare and endangered plant species of the Chinese Altai Mountains
}

\author{
Marina V. OLONOVA ${ }^{1 *}$, DaoYuan ZHANG ${ }^{2,3}$, ShiMing DUAN ${ }^{2,3}$, LinKe YIN $^{2,3}$, BoRong PAN ${ }^{2,3}$ \\ ${ }^{1}$ Tomsk State University, Tomsk 634050, Russia; \\ ${ }^{2}$ Key Laboratory of Biogeography and Bioresource in Arid Land, Xinjiang Institute of Ecology and Geography, Chinese Acad- \\ emy of Sciences, Urumqi 830011, China; \\ ${ }^{3}$ Turpan Eremophytes Botanical Garden, Xinjiang Institute of Ecology and Geography, Chinese Academy of Sciences, Turpan \\ 838008, China
}

\begin{abstract}
Altai (also named Altay in China) Mountain Country (Mountain System) is a unique natural region, located on the border between different floristic regimes of the Boreal and ancient Mediterranean sub-kingdoms, where distribution of plant species is actually limited. It is known to have sufficient endemic floral biodiversity in the Northern Asia. Many plants of Altai Mountain System need effective care and proper conservation measures for their survival and longer-term protection. Important Plant Area identified as the IUCN (the International Union for Conservation of Nature), specified criteria attract global attention for protection of floral biodiversity across the world. The records of 71 plant species from the Chinese Altai Mountains attributed to the criterion A and the dark conifer forests of Chinese Altai Mountains satisfied the criterion $\mathrm{C}$, which may help qualify to fulfill the national obligation of the Convention on Biological Diversity.
\end{abstract}

Keywords: conservation; Important Plant Area; endemics; Altai Mountain System

\section{Introduction}

The global biodiversity is known to be endangered now, and suffers seriously from the destruction of natural ecosystems, often caused by unwise human activities. According to the Convention on Biological Diversity, the system of special protected areas, also known as Important Plant Area (IPA), should become the base for supporting natural plant biodiversity and for sustainable use of plant resources. IPA is identified on the basis of three main criteria, including, A-globally and regionally threatened species, B-endemic, botanical richness and C-threatened habitats (Anderson, 2003). An area satisfying at least one or more of the above mentioned criteria can be qualified to be an IPA. The IPA program offers a means of identifying the threatened plants in those areas and determining that which of them have already being protected under the existing protected area systems i.e., national parks, reserves, and sanctuaries etc.

Altai Mountains are known to be the highest (4,506 $\mathrm{m}$ a.s.1.) among mountain systems of Northern Asia. It is situated in the Western of Altai-Sayan eco-region (Kamelin, 2005). It stretches from $44^{\circ} 30^{\prime} \mathrm{N}$ to ap- proximately $54^{\circ} \mathrm{N}$, and lies within the territories of Russia, China, Kazakhstan and Mongolia. The division of Altai Mountains had been argued and revised for several decades (Kamelin 1973, 2005; Takhtajan, 1978; Revushkin, 1988; Wu et al., 1996; Kamelin, 2005). Altai Mountains have extraordinary diversity and high endemism of floral species. Detailed manuals and guidelines for identifying IPA in Altai-Sayan eco-region has been published (Artemov et al., 2007). Having taken into account all peculiarities of the Siberian Flora, the researchers made the lists A (ii), A (iii), A (iv), and considering the vast territory of Russia and its federative arrangement, Artemov et al. (2007) proposed the introduction of new category A (v), which includes the species of local Red Data Book. Unfortunately, this manual only covered the eco-region of Russian, whereas the Altai Mountain System of Chinese part has not been included. Thus, in the paper, we have first reviewed the history of the division, the biodiversity situation, and the status of rare and endangered species of the Altai Mountains.

Received 2010-04-26, accepted 2010-07-21

doi: $10.3724 /$ SP.J.1227.2010.00222

*Corresponding author: Marina V. OLONOVA (olonova@green.tsu.ru) 
Secondly, we have tried to reveal the species of Chinese Altai flora stratified to criteria A, and have proposed the preliminary list of habitats, corresponding to criterion $\mathrm{B}$ and $\mathrm{C}$ of the IPA.

\section{Materials and methods}

The endemic and near endemic species were revealed, and their distribution was specified on the base of literature sources: Red Data Book of Kazakh SSR (1981), Red Data Book of Altai Republic (1996), Commission Redactorum Florae Xinjiangensis (1996), Red Data Book of Tyva Republic (1999), Red Data Book of Khakasia Republic (2002), Flora of China (Wu, 1994-2005), Red Data Book of Altaiskiy krai (2006), Red Data Book of Russian Federation (2008), Biodiversity of Altai-Sayan ecoregion and Database of plants and fungies (Biodiversity of Altai-Sayan Ecoregion, 2010).

The herbaria materials of AT, HAL, LE, MHA, MW, NS, NSK, PE, SSBG, TK and the collections of authors from Chinese parts of Altai Mountains were used to find out and specify species' distribution.

Geographic information system (GIS) software (ArcGIS 9) was used to map and digitize various floristic subdivisions of Altai Mountains to obtain the information on floristic provinces' boundaries in Chinese Alati Mountains (Kamelin, 2005).

\section{Results and discussion}

\subsection{The history of division, the biodiversity, the rare and endangered floral species of the Altai Mountains}

\subsubsection{Division of Altai Mountains}

Altai Mountains are located along the borders between different floristic provinces of Boreal and Ancient Mediterranean floristic sub-kingdoms (Takhtajan, 1978). It should be noticed that different authors mark these borders in different places, but all of them (Kamelin 1973, 2005; Revushkin, 1988; Wu et al., 1996) accept the frontier position of Altai. According to the last division (Kamelin, 2005), Altai Mountain Country includes the ridges Saur and Tarbagatai and its flora that is supposed to be formed on the bases of at least three different floral regimes, Boreal Euro-Siberian, Steppe and Ancient Mediterranean. As suggested by Kamelin $(1973,2005)$, botanical-geographical subdivision of Altai is based on three fundamental regions, including Boreal Mountainous South Siberian (Altai-West-Sayan floristic province), Sub-boreal Steppe Mountainous South Altai-Dzungarian (Altai-Dzungarian, also named Altay-Junggar in China) and Steppe-Desert Central Asian (Tuvinian-Mongolian), which completely reflect the floristic peculiarities of different regions of the Altai Mountain Country (Fig. 1). According to Kamelin

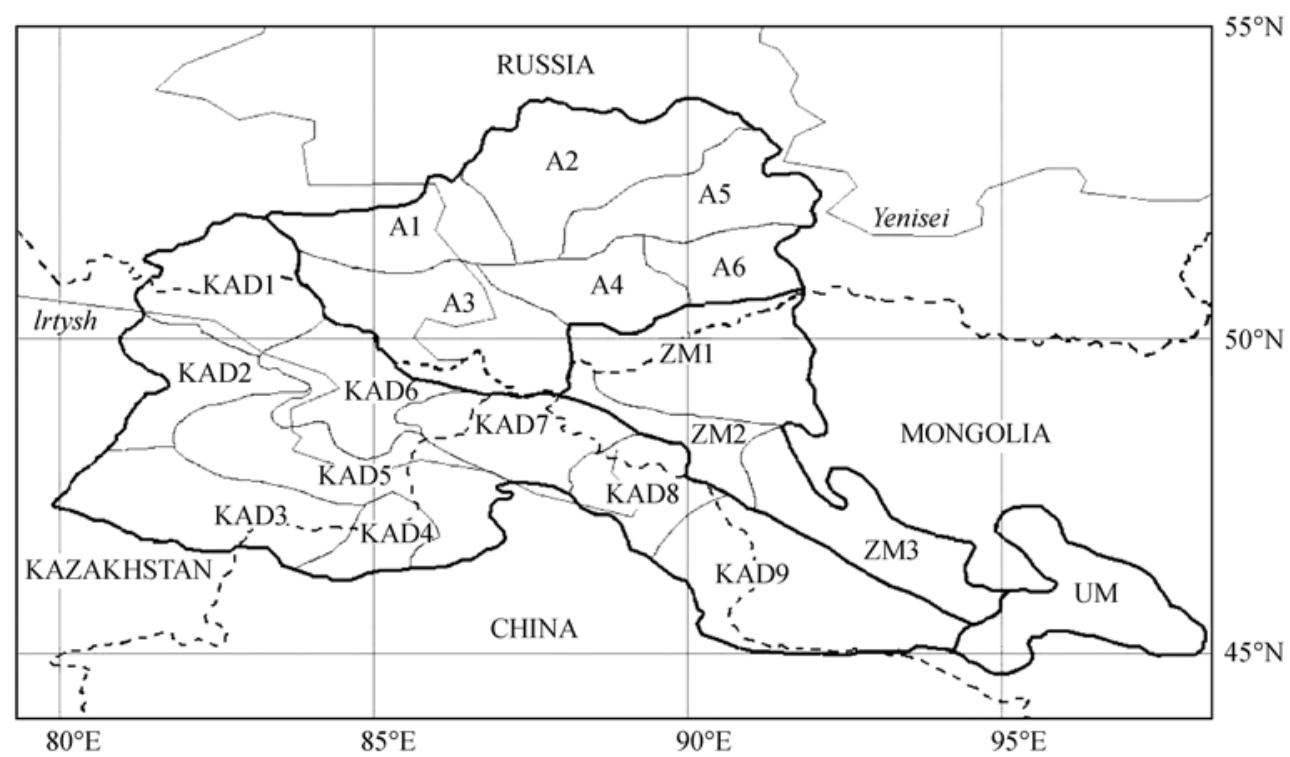

Fig. 1 Scheme of botanical-geographical subdivision of Altai (Kamelin, 2005)

A: Altai province (A1: Northern Altai, A2: North-Eastern Altai, A3: Central Altai, A4: Tchulyshman, A5: Abakan-Dzhebash, A6: Khemchik). KAD: Altai-Dzungarian province (KAD1: North-Westrn Altai, KAD2: Kalbinsky, KAD3: Tarbagatai, KAD4: Saur, KAD5: Zaissan, KAD6: Bukhtarma, KAD7: Markakol-Kanas, KAD8: Kara-Irtysh, KAD9: Altai-Dzungarian). ZM, UM: Tuvinian-Mongolian province (ZM1: Chuya-Khobdo, ZM2: Tsagan-Gol, ZM3: Khobdo-Tonkhil; UM: South-Mongolian 
(1973, 2005), the flora of Altai Mountains belongs entirely to the Circumpolar of the Boreal sub-kingdom, but to its different sub-regions, Altai-West Sayan belonging to Euro-Siberian sub-region, whereas both Altai-Dzungarian and Tuvinian-Mongolian provinces to Steppe sub-region. According to this division, Chinese Altai belongs to Altai-Dzungarian province. In China, it is represented by 6 sub-regions viz., Tarbagatai (KAD 3), Saur (KAD 4), Zaissan (KAD 5), Markakol-Kanas (KAD 7), Kara-Irtysh (KAD 8), and Altai-Dzungerian (KAD 9) (Fig. 1). Altai-Dzungarian floristic province as a whole is known to be very rich and original in floral biodiversity (Kamelin, 2005).

3.1.2 The Russian part of Altai Mountain System and the biodiversity

The Russian part of Altai Mountain System has 1,980 plants species, which perhaps is inferior to Ussury (South of Russian Far East) floristic region amongst the Asian parts of Russia (Malyshev et al., 2000). Kamelin (2005) indicated the flora of vascular plants of Altai Mountains as a whole having about 2,700 species at present. And, since 1998 the number of new species from this area has being reported (Chusovlianov, 1998, Ovchinnikova et al., 2004; German et al., 2006). Artemov et al. (2007) pointed out 252 endemic species of Altai-West Sayan floristic province as a whole (which includes other South Siberian mountains to the East Altai as well, but does not include KAD 3, KAD 4, and KAD 5 and KAD 9 (Kamelin, 2005)). Approximately, 125 species have been listed from the Altai Mountains alone. Piak et al. (2008) reported 288 endemic and sub-endemic (near endemic) plants of the Altai Mountain Country, which is not coincide with Artemov et al. (2007). The records of endemic and sub-endemic species from Altai Mountains have be extended, as new species are expected to be recorded from this poorly explored territory. Piak et al. (2008) has noted that over 30 endemic species have been found in this region during the last 15 years.

3.1.3 The Chinese part of Altai Mountain System and the biodiversity

Qian et al. (1956) subdivided the vegetation in China into 15 geo-botanical regions, recognized as 12 zones (vertical belts). In accordance with this subdivision, 3 zones of vegetation are characteristic for Chinese Altai: (1) Subarctic conifer forests (Aciculisilve); it occupies very restricted area, from the North in Altai to the West in Greater Khingan Mountains. Both of them represent the part of Siberian taiga, which wedged itself in Chinese territory. The main forest trees are conifers. Some of them are deciduous, and adapted to the cold, dry and long winter. In the forests of Altai Mountain System, Picea excelsa occurs on the river banks only, whereas Larix sibirica grows on quite elevated areas. The Southern parts and foothills of these forests are replaced gradually by forest-steppe communities and then by steppe. The meadows there are very close to West-European and Siberian ones. (2) Steppe and meadows (Terriherbosa) lies aside of sub-arctic conifer forests, mixed conifer and deciduous forests of temperate zone. From North-East to South-West in Northern Dzungarian the coverage of forests turns to be sparser with disappearance of high trees, and clear area, covered by expanded herbaceous xerophytes. Depending on the moisture conditions of this zone, it is divided into 2 sub-zones, meadow and steppe. In Altai Mountain System, meadows occupy the northern, more humid part $(500 \mathrm{~mm}$ annual precipitation). There are mesophytic grasses and forbs, such as Poa sibirica, Dactylis glomerata, Trisetum sibiricus, Anemone altaica, Pulsatilla flavescens, Paeonia anomala, Pedicularis spp., Aconitum spp. and Delphinium spp. Sub-zone of dry steppe occurs at the southern part of Chinese Altai (300 mm annual precipitation). Xerophytic grasses, such as Achnatherun splendens, Stipa sp., Cleistogenes squarrosa, and Koeleria sp. are developed there. The forbs are represented by Artemisia, Astragalus, Oxytropis, Potentilla, Serratula and Echinops.

Hou (1982) indicated 3 vegetation types within Chinese Altai: (1) Needle-leaved deciduous forests (light taiga) on the mountains of the cold temperate zone or temperate zone. According to the research of Chang (1955), larch forests, being light demanding, can endure a greater degree of dryness than spruce and fir. They can be found either on dry, sunny slopes or in moist valleys and lowlands. In Chinese Altai, the dominant tree species are replaced by Larix sibirica, which often grows with Pinus sibirica. Rhododendron dahuricum appears frequently in the shrub layer of this forest. (2) Needle-leaved evergreen forests (dark taiga) can be seen on the mountains of temperate zone. Chen et al. (1964) indicated the shady coniferous forests 
dominated by Picea obovata, Abies sibirica and Pinus sibirica, are confined to the northwestern most corner of Altai Mountains, probably due to relatively higher humid climate of the region. (3) The mountain dwarf-shrub tundra is poorly developed on the summit of the temperate high mountains of Altai. The soil is acidic in nature, and the climate is characterized by high humidity, strong winds, permafrost, and short growth season. Vegetation consists of dense growth of evergreen dwarf shrubs, mainly belonging to the Ericaceae, with about $10-20 \mathrm{~cm}$ height and small and tough leaves (Vaccinium vitis-idea, Empetrum nigrum) and deciduous shrubs, such as Salix rotundifolia, Betula rotundifolia.

The Vegetation Map of China (Hou et al., 1982) has covered dry savannah and short grasslands, the boreal deciduous forests, boreal conifer forests, temperate (boreal) mixed forests and temperate conifer forests for the Chinese Altai Mountains.

Kamelin (2005) paid attention to great diversity of vegetation in Altai-Dzungarian floristic province, but, while describing it, he meant the province as whole, because Chinese Altai covers about $50 \%$ of the whole floristic province. Nevertheless, it should be noticed, that he founds Altai-Dzungarian floristic province to be the richest in plant species within Altai Mountains System. It contains a lot of nemoral "chernevaya" taiga species. For example, the species of Anemone umbrosa, Eutrema integrifolium, Campanula latifolia and Codonopsis clematidea are endemic to this region, whereas numerous other species are quite common within Altai Mountains System. Some species, belonging to relic "quercetal" species, have been recorded there, mainly being connected with mesophylous bush communities. These species, such as Daphne altaica, Clematis integrifolia, Gymnospermum altaicum, Potentilla rupestris and some other floral species of the province with oak forest-steppe regions of East and Central Europe are much rare. A lot of species with different relationships and origins, such as Sibirea laevigata, Dictamnus angustifolius, Stelleropsis altaica etc. represent the element of Middle Asia Mountains. Flora of Zaissan and Barun-Kurai depressions contains numerous Turanian, Turanian-Dzungarian, Northern Turanian-Dzungarian desert elements (Stipagrostis pennata, Carex physoides, Ammodendron bifolium, etc.) and Gobian de- sert-steppe and desert species (Allium polyrhizum, Zygophyllum xanthoxylon,etc). In addition, Kamelin (2005) considered the flora of the province to be highly original, and adduces more than 100 endemic, such as Limnas vereszcaginii, Allium caespitosum, A. robustum, Iris ludwigii etc. So, it should be paid attention to Altai-Dzungarian floristic province as a whole, including its Kazakhstanian part, nevertheless it gives a good notion about its diversity, floral resources and reasons for their conservation.

\subsection{Rare and endangered plants in Chinese Altai}

All the documents mentioned above indicated the Chinese Altai territory being of high botanical value. Nevertheless, this territory, being very attractive for tourism and business, now is known to be under great anthropogenic press and its flora and vegetation need special protection. Criteria, which were recommended for IPA identification, are applicable to Chinese Altai territory. Particularly, an identification of the IPA could be a step towards realizing this program.

\subsubsection{The species of Criterion A}

An analysis of literature sources and herbarium materials listed above has revealed 265 endemic species. Only 32 endemic species are recorded in China (Table 1). Comparison with other countries, 171 endemic species in Russian Altai Mountains, 105 in Kazakhstan Altai Mountains and 99 in Mongolian Altai Mountains, the endemic species recorded in China are not completed.

The list of threatened species of Chinese Altai consists of 35 species (Table 2), and only one of them, Delphinium eglandulosum C.Y. Yang et B. Wang, is endemic to Chinese Altai and may be attributed to list A (iii). Some species under protection, i.e. Alisma nanum D.F.Cui, Atraphaxis jrtyschensis C.Y. Yang et Y.L. Han, Betula halophila Chung ex P.C.Li, Delphinium eglandulosum C.Y. Yang et B.Wang, and Erigeron songaricus $\mathrm{Y}$.Wei et $\mathrm{Z} . \mathrm{X}$ are amongst the Chinese national endemics. Their distribution is limited to China only and the communities with their participation are supposed to be identified as IPA, following the recommendation A (iii) of the Convention on Biological Diversity (Anderson, 2002). In accordance with recommendations for identifying IPA, the sub-endemics (near to endemic species) are also to be protected. 
Table 1 Endemic species of Chinese Altai Mountains and the distribution in the different courtiers

\begin{tabular}{|c|c|c|c|c|}
\hline Species & China & Russia & Kazakhstan & Mongolia \\
\hline Delphinium eglandulosum C.Y.Yang et B.Wang & + & - & - & - \\
\hline Delphinium inconspicuum Serg. & + & + & + & + \\
\hline Mesostemma martjanovii (Kryl.) Ikonn & + & + & - & - \\
\hline Stellaria imbricata Bunge & + & + & + & - \\
\hline Atriplex altaica Sukhor & + & + & + & - \\
\hline Limonium congestum (Ledeb.) O. Kuntze & + & + & + & - \\
\hline Stelleropsis altaica (Theib.) Pobed. & + & + & - & + \\
\hline Rhodiola algida (Ledeb.) Fisch. et C.A. Mey & + & + & + & + \\
\hline Sibiraea laevigata (L.) Maxim & + & + & - & + \\
\hline Astragalus burtschumensis Saposhn. ex Sumn. & + & - & - & + \\
\hline Astragalus kurtschumensis Bunge & + & - & + & + \\
\hline Astragalus majevskianus Kryl. & + & - & + & + \\
\hline Astragalus pseudotesticulatus Sancz. et Ulzij & + & - & + & - \\
\hline Astragalus scleropodus Ledeb. & + & - & - & + \\
\hline Astragalus xanthotrichus Ledeb. & + & - & - & + \\
\hline Astragalus zaissanensis Sumn. & + & - & + & + \\
\hline Oxytropis martjanovii Kryl. & + & + & + & - \\
\hline Craniospermum subfloccosum Kryl. & + & + & + & + \\
\hline Mertensia pallasii (Ledeb.) G. Don fil. & + & + & - & + \\
\hline Mertensia tarbagataica B.Fedtsch & + & - & - & + \\
\hline Euphrasia schischkinii Serg. & + & + & + & + \\
\hline Pedicularis abrotanifolia Bieb. ex Steven & + & + & + & + \\
\hline Pedicularis altaica Bieb. ex Steven & + & + & + & + \\
\hline Dracocephalum bungeanum Schischk. et Serg. & + & + & + & - \\
\hline Laphanthus krylovii Lipsky & + & + & + & + \\
\hline Nepeta densiflora Kar. et Kir. & + & - & + & + \\
\hline Panzeria canescens (Bunge) Sojak. & + & + & + & - \\
\hline Iris kamelinii Alexeeva & + & + & - & - \\
\hline Gagea kuraiensis Levichev & + & + & - & - \\
\hline Elymus karakabiensis Kotukh. & + & + & - & + \\
\hline Poa veresczaginii Tzvel. & + & + & - & + \\
\hline Stipa sczerbakovii Kotukh & + & - & - & + \\
\hline
\end{tabular}

These species are distributed in China and Kazakhstan, but their area is not limited to Altai Mountains. The following species listed in Table 2 may be attributed to this group, such as Fritillaries pallidiflora Schrenk (Red Data Book of Kazakh SSR, 1981; Ivaschenko, 2005), Fritillaria walujewii Regel (Wu, 1994-2005), Gymnospermium altaicum (Pall.) Spach (Red Data Book of Kazakh SSR, 1981; Red Data Book of Altaiskiy krai, 2006), Trapa zaissanica (Fler.) V. Vassil. (Wu, 1994-2005), Polygonum glaresum Scischk. P. schischkinii Ivanova ex Borodina (Wu, 1994-2005;
Borodina, 1989) and Saussurea involucrata. Their distribution is in 2 or 3 countries, but all their locations are within Altai Mountains. Thus, being near endemic in their countries may be attributed to A(iv), 31 species of Altaic endemics, listed in Table 2 may be also considered as national sub-endemics and can be added to the list of the threatened species of Xinjiang.

As for the groups of species under protection in Xinjiang, some of them distributed widely, but their limited distribution lies within the Northern flanks of China or in Chinese Altai. The limited distribution 
Table 2 The threatened plant species of Altai region in Xinjiang

\begin{tabular}{|c|c|c|}
\hline Species & Species & Species \\
\hline Abies sibirica Ledeb. & Erigeron songaricus Y.Wei et Z.X. An & Nymphaea candida C.Presl. \\
\hline Adonis villosa Ledeb. & Erythronium sibiricum (Fisch. et Mey.) Kryl & Oxalis acetosella $\mathrm{L}$. \\
\hline Adoxa moschatellina $\mathrm{L}$. & Fritillaria pallidiflora Schrenk & Phyllodoce caerulea Babington \\
\hline Alisma nanum D.F.Cui & Fritillaria walujewii Regel & Picea obovata Ledeb. \\
\hline Allium altaicum Pall. & Gentiana algida Pall. & Pinus sibirica Du Tour. \\
\hline Astragalus penduliflorus Lam. & Gymnocarpium altaicum C.Y. Yang & Polygonum glareosum Scischk \\
\hline Atraphaxis jrtyschensis C.Y. Yang et Y.L. Han & Gymnospermium altaicum (Pall.) Spach & Populus nigra $\mathrm{L}$. \\
\hline Betula halophila Chung ex P.C.Li & Juniperus sabina L. & Pulmonaria mollissima Kern. \\
\hline Circaea lutetiana $\mathrm{L}$. & Leymus racemosus (Lam.) Tzvel. & Saussurea involucrata (Kar. et Kir.) Bip. \\
\hline Daphne altaica Pall. & Lilium martagon var. pilosiusculum Freyn. & Sorbus sibirica Hedl. \\
\hline Delphinium eglandulosum C.Y. Yang et B.Wang & Megacarpaea megalocarpa (Fisch. ex DC.) Fedtsch & Tussilago farfara $\mathrm{L}$. \\
\hline Empetrum nigrum $\mathrm{L}$. & Nuphar pumilum (Hoffm.) DC. & \\
\hline
\end{tabular}

made them vulnerable and (or) rare. Special protection measures are needed to ensure their longer-term survival in the area. This is why we should support the suggestion of adding the A (v) category (Artemov et al., 2007); and the other 19 species should be included to the list.

Phyllodoce caerulea Babington is arctoalpine species. In spite of being distributed both in Eurasia and America, it is quite rare on the southern part, and only penetrates into the Altai Mountains of Chinese territory. Abies sibirica Ledeb., Erythronium sibiricum (Fisch. et Mey.) Kryl., Picea obovata Ledeb. and Pinus sibirica Du Tour. (Siberian boreal species and being a part of sub-arctic conifer forests) are rare and vulnerable in China (Fig. 2). Boreal species Adoxa moschatellina L., Sorbus sibirica Hedl., Empetrum nigrum L., Oxalis acetosella, Lilium martagon var. pilosiusculum Freyn, Nuphar pumila are quite broad Eurasian distribution and occur in China both in the NW (Altai) and NE, together with conifer forests. Contrasted with them, Nymphaea candida C. Presl and Populus nigra L. do not propagate too far to the East. Nymphaea candida has some isolated locations in the Eastern Siberia, whereas Populus nigra does not occur in the East of Yeniswy River at all. The range of Eurasian Juniperus sabina L. is fragmented, and the southeast limit of its distribution is in the Chinese Altai as well (Hultén, 1986).
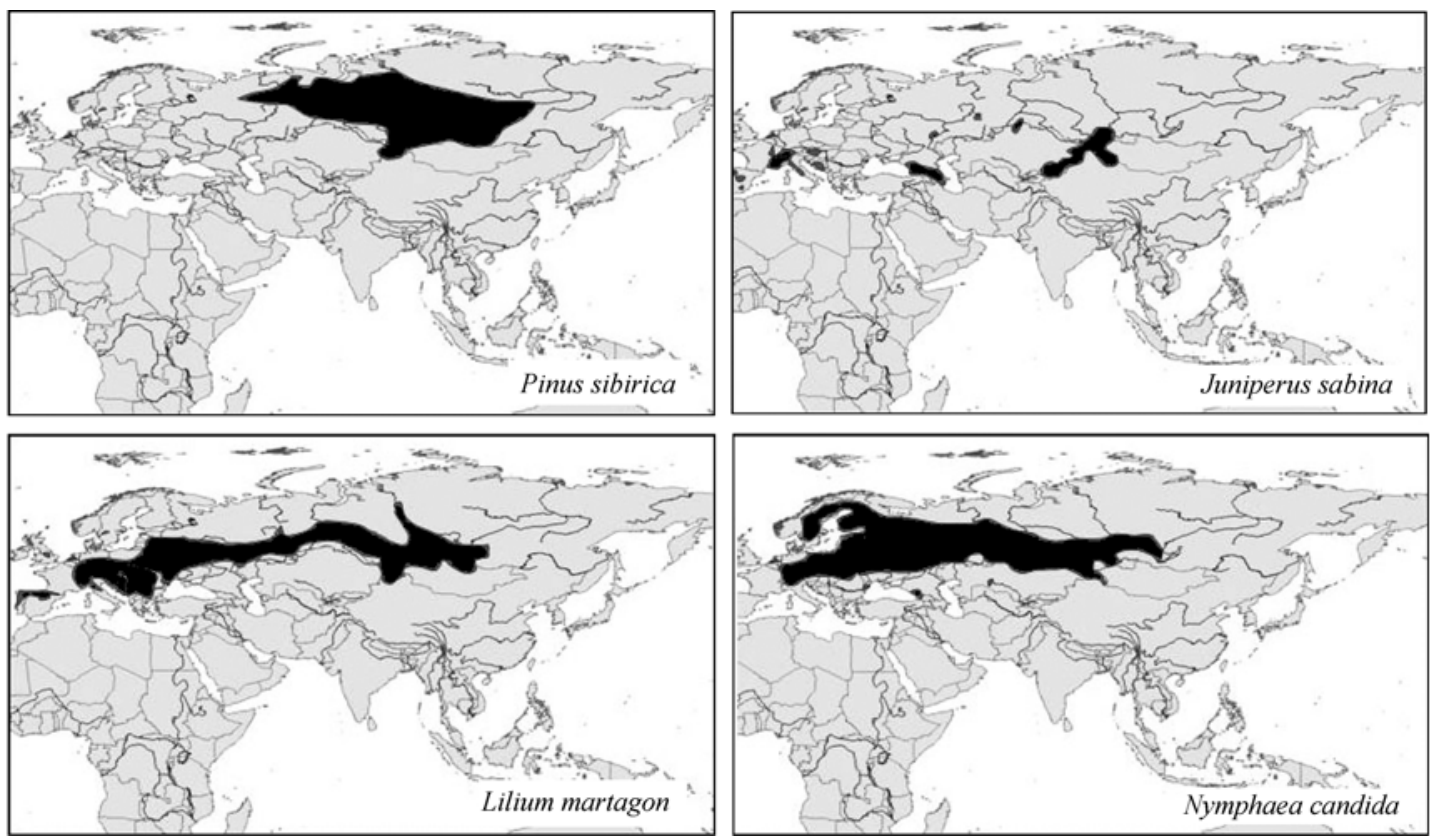

Fig. 2 Geographical distribution of Pinus sibirica, Juniperus sabina, Lilium martagon and Nymphaea candida 
Stemmacantha carthamoides Wild. is distributed in Siberia, Kazakhstan, Xinjiang of China and Mongolia. It has been declared to be vulnerable in China, Russia and Kazakhstan, and has been included in the national Red Data books (Red Data Book of Kazakh SSR, 1981; Red Data Book of Altai Republic, 1996; Red Data Book of Russian Federation, 2008) and regional Red Data book (Red Data Book of Altaiskiy krai, 2006). Other valuable medicinal (Adonis villosa Ledeb.) and food (Allium altaicum Pall.) plants with restricted distributions are included in the Red data books of Altai Republic and Altaiskiy krai as vulner- able and endangered species.

The distribution of some of the species is sufficiently fragmented into ranges in the Altai territory, which are considered to be relics like Daphne altaica Pall. (Red Data Book of Kazakh SSR, 1981; Red Data Book of Altai Republic, 1996; Red Data Book of Russian Federation, 2008), Circaea lutetiana L. (Polozhiy, 1985; Krapivkina, 1985), Saussurea involucrata (Kar. et Kir.) Bip. (Red Data Book of Kazakh SSR, 1981). The investigations show that almost 71 species recorded from the Chinese Altai territory may be included into the category A (Table 3 ).

Table 3 The species of Chinese Altai Mountains attributed to criterion A

\begin{tabular}{|c|c|c|c|}
\hline Criterion & Species & Criterion & Species \\
\hline A iii & Alisma nanum D.F.Cui & A iv & Circaea lutetiana $\mathrm{L}$. \\
\hline A iii & Atraphaxis jrtyschensis C.Y. Yang et Y.L. Han & A iv & Craniospermum subfloccosum Kryl. \\
\hline A iii & Atriplex altaica Sukhor. & A iv & Daphne altaica Pall. \\
\hline A iii & Delphinium eglandulosum C.Y. Yang et B.Wang & A iv & Delphinium inconspicuum Serg. \\
\hline A iii & Erigeron songaricus Y.Wei et Z.X. An & A iv & Dracocephalum bungeanum Schischk. et Serg. \\
\hline A v & Abies sibirica Ledeb. & A iv & Elymus karakabiensis Kotukh \\
\hline A v & Adonis villosa Ledeb. & A iv & Empetrum nigrum $\mathrm{L}$. \\
\hline A v & Adoxa moschatellina $\mathrm{L}$. & A iv & Erigeron altaicus M.Pop. \\
\hline A v & Erythronium sibiricum (Fisch. et Mey.) Kryl. & A iv & Euphrasia schischkinii Serg. \\
\hline A v & Gentiana algida Pall. & A iv & Fritillaria pallidiflora Schrenk \\
\hline A v & Juniperus sabina $\mathrm{L}$. & A iv & Fritillaria walujewii Regel. \\
\hline A v & Laphanthus krylovii Lipsky. & A iv & Gagea kuraiensis Levichev \\
\hline A v & Leymus racemosus (Lam.) Tzvel. & A iv & Gymnocarpium altaicum C.Y. Yang \\
\hline A v & Lilium martagon var. pilosiusculum Freyn. & A iv & Gymnospermium altaicum (Pall.)Spach. \\
\hline A v & Nuphar pumilum (Hoffm.)DC. & A iv & Iris kamelinii Alexeeva \\
\hline $\mathrm{Av}$ & Nymphaea candida C.Presl & A iv & Limonium congestum (Ledeb.) 0 . Kuntze \\
\hline A v & Oxalis acetosella $\mathrm{L}$. & A iv & Mertensia pallasii (Ledeb.) G. Don fil. \\
\hline $\mathrm{A} \mathrm{v}$ & Phyllodoce caerulea Babington & A iv & Mertensia tarbagataica B.Fedtsch. \\
\hline A v & Picea obovata Ledeb. & A iv & Mesostemma martjanovii (Kryl.) Ikonn. \\
\hline A v & Pinus sibirica Du Tour & A iv & Nepeta densiflora Kar. et Kir. \\
\hline A v & Populus nigra L. & A iv & Oxytropis martjanovii Kryl. \\
\hline $\mathrm{A} \mathrm{v}$ & Pulmonaria mollissima Kern. & A iv & Panzeria canescens (Bunge)Sojak. \\
\hline A v & Sorbus sibirica Hedl. & A iv & Pedicularis abrotanifolia Bieb. ex Steven \\
\hline$A v$ & Tussilago farfara $\mathrm{L}$. & A iv & Pedicularis altaica Bieb. ex Steven \\
\hline A v & Abies sibirica Ledeb. & A iv & Poa veresczaginii Tzvel. \\
\hline A v & Adonis villosa Ledeb. & A iv & Polygonum glareosum Scischk \\
\hline$A v$ & Adoxa moschatellina $\mathrm{L}$. & A iv & Ptarmica ledebourii (Heimerl.)Serg. \\
\hline A iv & Allium altaicum Pall. & A iv & Pyrethrum alatavicum (Herd.)O. et B. Fedtsch \\
\hline A iv & Astragalus burtschumensis Saposhn. ex Sumn. & A iv & Rhodiola algida (Ledeb.) Fisch. et C.A. Mey. \\
\hline A iv & Astragalus kurtschumensis Bunge. & A iv & Saussurea involucrata (Kar. et Kir.)Bip. \\
\hline A iv & Astragalus majevskianus Kryl. & A iv & Sibiraea laevigata (L.) Maxim \\
\hline A iv & Astragalus penduliflorus Lam. & A iv & Stellaria imbricata Bunge. \\
\hline A iv & Astragalus pseudotesticulatus Sancz. et Ulzij. & A iv & Stelleropsis altaica (Theib.)Pobed. \\
\hline A iv & Astragalus scleropodus Ledeb. & A iv & Stemmacantha carthamoides Willd. \\
\hline A iv & Astragalus xanthotrichus Ledeb. & A iv & Stipa sczerbakovii Kotukh \\
\hline A iv & Astragalus zaissanensis Sumn. & A iv & Trapa zaissanica (Fler.)V.Vassil. \\
\hline A iv & Betula halophila Chung ex P.C.Li & & \\
\hline
\end{tabular}




\subsubsection{The species of Criteria B and C}

Following the recommendations for identifying IPA (Anderson, 2002), to qualify as an IPA needs to satisfy one or more of the aforementioned criteria (A, B and C). Based on the results of the mentioned above, there are a lot of original and rich species in Chinese Altai Mountains, which may be qualified as an IPA in accordance with criteria B and C. Criterion B is supposed to have an exceptionally rich flora in a European context in relation to its bio-geographic zone. The areas that satisfy to the criterion $\mathrm{C}$ are outstanding examples of habitat types, of the global or European plant conservation and botanical important (Anderson, 2002). The dark conifer forests of Chinese Altai, composed of Pinus sibirica, Abies sibirica and Picea obovata with numerous herbaceous boreal species, may be qualified as habitats, satisfied to criterion C. In accordance with classification, accepted by European Nature Information System (2004), which were transformed from Altai-Sayan region (Artemov et al, 2007), these plant communities should be attributed to the type G3.1.-dark conifer forests with predominated Abies, Picea and Pinus sibirica. These communities are common for Siberia, but many botanists considered them to be very rare in Xinjiang and other regions of China (Qian et al., 1956; Hou, 1982). These sites in the Chinese Altai are on their southern border of distribution. Being rare, these species need special conservation measures.

Nevertheless, careful search of plant lists, included in the Red Data Books of adjacent territories, and their distribution, allows to assume that the Chinese list of rare plants (particularly, Chinese Altai) is not comprehensive and new rare species may be revealed on the frontier territories. It should be taken into consideration that Chinese part of Altai Mountains System, as well as Kazakhstan, are situated within the Altai-Dzungarian floristic province, which is known to be the richest in species diversity. On the frontiers between China and Kazakhstan, Tarbagatai, Saur, Zaissan and Markakol-Kanas floristic regions are known to be the richest in endemics in Kazakhstan Altai. This means that variety of floristic resources of

\section{References}

Anderson S. Identifying Important Plant Areas: A Site Selection Manual for Europe, and A Basis for Developing Guidelines for Other this territory has not been sufficiently explored yet, and more detailed investigations are needed to record the endemic species from both the whole Altai Mountains and the Chinese Altai Mountains.

\section{Conclusions and suggestion}

In the paper, we critically reviewed the plant species in the Chinese Altai Mountains and classified 71 species into category A. The Chinese Altai territory, a place of high botanical and aesthetic value needs special protection measures for long-term research and conservation. The following recommendations $\mathrm{s}$ ld be taken into account for this purpose:

(1) Reveal the plant diversity in the frontier territories.

(2) Identify IPA based on criteria A (threatened species), B (botanical richness) and $\mathrm{C}$ (threatened habitats).

(3) Monitor the selected areas in specified states.

(4) Introduce sustainable use of plant resources.

(5) Promote education and awareness about plant diversity, endemism and traditional uses.

These measures are necessary for the protection of Altai biodiversity because of the intensification of human activities. And it may be considered as a step to fulfill the national obligations implied under the purview of Convention on Biological Diversity. The 71 species from Chinese Altai Mountains could be attributed to the criterion A. The dark conifer forests of Chinese Altai, composed by Pinus sibirica, Abies sibirica and Picea obovata with numerous herbaceous boreal species, satisfy the criterion C. As for criterion $\mathrm{B}$, it concerns the area with the highest biodiversity, and the list of these species need a very detailed search of territory. Therefore the area can not be recommended, only based on our present-day data.

\section{Acknowledgements}

The research was supported by the Xinjiang Committee of Science and Technology (200933122). The authors gratefully acknowledge the help of the curators of herbaria AT, HAL, LE, MHA, MW, NS, NSK, PE, SSBG, TK.

Regions of the World. London: Plantlife International Production, 2002 
Artemov I I, Korolyuk Yu A, Lashchinskiy NN, et al. Criteria for choosing the key botanical territories within Altai-Sayan ecoregion. Novosibirsk: Siberian Ecologic Center, 2007. 106.

Biodiversity of Altai-Sayan Ecoregion. Database of plants and fungies. 2003. [2010-01-12] http://www.bioaltai-sayan.ru/regnum/.

Borodina A E. Polygonum. In: Grubov V I. Plantae Asia Cnetral. Leningrad: Nauka, 1989. 100-123.

Chang Y L. The plant communities of the Greater Khingan Mountains. In: Complication and Translation Commission of Chinese Academy of Sciences: Contribution to Plant Ecology and Geobotany. Beijing: Science Press, 1955. 1.

Chusovlyanov D V. A new species of the genus Festuca (Poaceae) from Altai. Botanicheskiy Journal. 1998. 83(11): 113-115.

Commission Redactorum Florae Xinjiangensis. Flora Xingjiangensis. Urumqi: Xinjiang Science and Technology and Hygiene Publishing House, 1996. 6. 670.

Editoral Committee for Vegetation of China. Vegetation of China. Beijing: Science Press, 1980.

European Nature Information System (EUNIS). 2005.[2004-08-11]. http://eunis.eea.eu.int/index.jsp.

German D A, Shmakov A I, Zhang X.C, et al. Some new floristic finding in Xinjiang, China. Acta Phytotaxonomica Sinica. 2006. 44(5): 598-603.

Hou X Y. Vegetational Geography and Chemical Components of Dominant Plants in China. Beijing: Science Press, 1982.

Hultén E, Fries M. Atlas of North European Vascular Plants North of the Tropic of Cancer. Konigstein: Koeltz Scientific Books, 1986.

Ivaschenko A A. Tulips and Other Bulbs Plants of Kazakhstan. Almaty: Two Capitals, 2005. 192.

Kamelin R V. Florogenetical Analisys of Natural Flora of Mountain Middle Asia. Leningrad: Nauka, 1973. 355.

Kamelin R V. The Materials for the History of Flora of Asia (Altai Mountain Country). Barnaul: Altaiskogo gosuniversiteta, 1998. 240.

Kamelin R V. Brief Characteristics of Natural Conditions and Vegetation of Altai Mountain Country, Flora Altaica. Barnaul: Azbuka, 2005. $1,68-97$.

Malyshev L I, Baikov K S, Doronkin V M. Floristic division of Asiatic
Russia on the basis of quantitative data. Krylovia. 2000. 2(1): 3-16.

Ovchinnikova S V, Pjak A I, Ebel A L. Novelties in the genus Lappula (Borraginaceae) of the Altai Mountain system. Turzcaninovia. 2004. 7 (2): 5-13.

Piak A I, Shaw S C, Ebel A L. et al. Endemic Plants of the Altai Mountain Country. London: Wild Guides. 2008. 320.

Polozhiy A V, Krapivkina E D. The Relics of Tertiary Broad Leave Forests in the Flora of Siberia . Tomsk: Tomsk State University, 1985. 158.

Qian C S, Wu Z Y, Chen C D. A tentative scheme for plant geographic region. Editorial Board for Chinese Geography. Tentative Scheme for Natural Regionalization of China. Beijing: Science Press, 1956. 83-142.

Red Data Book of Altai Republic. Rare and Vulnerable Plants Species. Novosibirsk: CSBG SB RAS, 1996. 130.

Red Data Book of Altaiskiy krai. Rare and Vulnerable Plants Species. Barnaul: OAO “IPP Altai”, 2006.262.

Red Data Book of Kazakh SSR, Rare and Vulnerable Species of Animals and Plants. Part. 2. Plants. Alma-Ata: Nauka KazSSR, 1981. 260.

Red Data Book of Khakasia Republic. Rare and Vulnerable Species of Plants and Fungies. Novosibirsk: Nauka, 2002. 264.

Red Data Book of Russian Federation, Plants and Fungies. Moscow: KMK, 2008. 455.

Red Data Book of Tyva Republic. Plants. Novosibirsk: SB RAS, 1999.150.

Revushkin A S. Alpine Flora of Altai. Tomsk: Tomsk State University, 1988. 320.

Takhtajan A L. Floristical Provinces of Earth. Leningrad: Nauka, 1978. 248.

Wu Z Y, Raven R R. Flora of China. Beijing: Science Press, St Louis: Missuri Botanical Garden Press, 1994-2005. 5, 13, 24.

$\mathrm{Wu} \mathrm{Z}$, Wu S. A proposal for a new floristic kingdom (realm): the E. Asiatic Kingdom, its delineation and characteristics. In: Zhang A L, Wu S G. Floristic Characteristics and Diversity of East Asian Plants. Proceedings of the First International Symposium of Floristic Characteristics and Diversity of East Asian plants. Berlin: Springer Verlag, Beijing: China Higher Education Press, 1998. 3-42. 